\title{
Intergovernmental Coordination without the Big Polluters
}

\author{
Jan-Erik Lane \\ University of Geneva, Geneva, Switzerland \\ Email: janeklane@gmail.com
}

How to cite this paper: Lane, J.-E. (2020). Intergovernmental Coordination without the Big Polluters. Open Journal of Political Science, 10, 732-738.

https://doi.org/10.4236/ojps.2020.104042

Received: July 19, 2020

Accepted: October 17, 2020

Published: October 20, 2020

Copyright (C) 2020 by author(s) and Scientific Research Publishing Inc. This work is licensed under the Creative Commons Attribution International License (CC BY 4.0).

http://creativecommons.org/licenses/by/4.0/

\begin{abstract}
Human beings have existed as modern homo sapiens for some 100,000 years, recent DNA research informs. And this race has grown to a staggering 8 billion almost, dominant over all other living species and subjugating the other human races. The 21st century may end the fantastic story about Cro-Magnons as planet Earth no longer may support advanced forms of life, i.e. low temperature, supply of food, access to drinking water as well as absence of war between or within nations and even civilisations. Only intergovernmental coordination can slow the process of climate change, but the nature of international relations prohibits it.
\end{abstract}

\section{Keywords}

Intergovernmental Coordination, Big Polluters, Climate Change Gaming, Chaos

\section{Introduction}

Country differences in government response to Nature's challenges to mankind differ. What is extremely important is that policies do not aggravate the situation for humanity. However, some governments fuel chaos in the fight against the COVID. How about global policies towards climate changes? Could intergovernmental coordination work? Mankind is ravaged by a coronavirus-COVID weakening social systems and states. COVID-19 has caused chaos in several countries, see Table 1.

Some numbers are shocking. The lack of a proper uniform response is significant, and it could come from intergovernmental coordination. The policy guidelines of the WHO were neglected by the worst-off countries. At the same time, biologists and Earth Scientists emphasize that global warming is spinning out of control, fueled by the set of tipping points. 
Table 1. Outcomes of COVID as of August 31, 2020 (Worldometers).

\begin{tabular}{ccccc}
\hline Country & Total & Total & Tot Cases/ & Deaths/ \\
\hline USA & Cases & Deaths & 1 M pop & 1 M pop \\
Russia & $6,218,003$ & 187,902 & 18,767 & 567 \\
Spain & $1,000,048$ & 17,299 & 6852 & 119 \\
UK & 462,858 & 29,094 & 9899 & 620 \\
Italy & 337,168 & 41,504 & 4962 & 611 \\
Germany & 269,214 & 35,491 & 4454 & 587 \\
France & 245,408 & 9377 & 2927 & 112 \\
China & 281,025 & 30,635 & 4304 & 469 \\
Sweden & 85,058 & 4634 & 59 & 3 \\
\hline
\end{tabular}

\section{International Anarchy}

Anarchism as political theory is paradoxical. On the one hand, it has few adherents when it is a matter of the domestic polity-although sup and ported by none less than Prudhoun, Bakunin, Tolstoy, Krapotkin and Chomsky. On the other hand, it is the prevailing doctrine about international relations. Here it is called realism coming in different versions, more rational or more aggressive (Bull, 1977; Waltz, 2008). A major theoretician is Hans Morgenthau. Realism in the theory of international relations implies that governments operate under uncertainty in order to maximize their own interests. Hobbes (1651) rejected domestic anarchism but endorsed the international anarchy.

However, the opposite approach to international relations underlines institutions that restrain states to honour agreements and cooperate peacefully. Here, we have the theory of normativity. It has grown in relevance since World War War two. But we are far from a world federation (Kant) or Humanity's Law (Teitel, 2011). Jurists have outlined global constitutionalism with the hope of peace through law (Kelsen, 1952).

Intergovernmental coordination is slow and cumbersome. Transaction costs tend to skyrocket. But it is sometimes successful like global economic governance by the WB, IMF and the WHO. Moreover, international governance succeeded in resolving the ozone layer problem, at least temporarily. Why, then, does not climate change policies work? Because the Bigpolluters stand by the sidelines, watching only what happens at the UN mega reunions.

\section{Lack of Normativity Globally}

To understand the pollution of Earth by greenhouse gases one must identify the major polluters. The governments of the nations of the world have delayed action on climate change for more than 30 years. The next IPCC conference has been postponed until late 2021 . What interests do governments pursue in climate change policy making? 
First, one needs to focus on which states are responsible for the most emissions. Tables 2-4 present the 10 biggest polluters of $\mathrm{CO}_{2}, \mathrm{CH}_{4}$, and $\mathrm{N}_{2} \mathrm{O}$, respectively-the "Mega Polluters".

Given that only some 10 countries produce more than half of the world's greenhouse gases, it is a remarkable fact that small countries, aiming zealously at zero emissions don't matter at all.

\section{The Costs of $\mathrm{CO}_{2}$ Reduction}

$\mathrm{CO}_{2}$ molecules stay in the atmosphere for very long time periods, so they must be removed very soon. Dreaming about negative carbon emissions would require the construction of enormous numbers of carbon capture plants, or the total replacement of coal-fired electricity by solar energy. Table 5 provides an estimate of how many World-class solar plants each of the leading polluters would have to introduce to replace all of their coal-fired capacity.

Table 2. 10 world leading emitters of $\mathrm{CO}_{2}$ (Burton, n.d.).

\begin{tabular}{ccc}
\hline Country & Emissions/billion tonnes & Share/\% \\
\hline China & 9.4 & 27.8 \\
United States & 5.2 & 15.2 \\
India & 2.5 & 7.3 \\
Russia & 1.5 & 4.6 \\
Japan & 1.1 & 3.4 \\
Germany & 0.7 & 2.1 \\
South Korea & 0.7 & 2.1 \\
Iran & 0.7 & 1.9 \\
Saudi Arabia & 0.6 & 1.7 \\
Canada & 0.6 & 1.6 \\
Total & 23 & 67.7
\end{tabular}

Table 3. 10 leading emitters of $\mathrm{CH}_{4}$ (Burton, n.d.).

\begin{tabular}{ccc}
\hline Country & Emissions/gt CO$_{2}$ equivalent & Share/\% \\
\hline China & 1.75 & 21.87 \\
India & 0.64 & 7.94 \\
Russia & 0.55 & 6.81 \\
United States & 0.50 & 6.24 \\
Brazil & 0.48 & 5.95 \\
Indonesia & 0.22 & 2.79 \\
Pakistan & 0.16 & 1.98 \\
Australia & 0.13 & 1.57 \\
Iran & 0.12 & 1.51 \\
Mexico & 0.12 & 1.46 \\
Total & 4.66 & 58.11 \\
\hline
\end{tabular}


Table 4. 10 leading emitters of $\mathrm{N}_{2} \mathrm{O}$ (EDGAR).

\begin{tabular}{ccc}
\hline Country & Emissions $/ \mathrm{mt} \mathrm{CO}_{2}$ equivalent & Share $\%$ \\
\hline China & 587.2 & 18.6 \\
United States & 288.9 & 9.2 \\
India & 239.8 & 7.6 \\
Brazil & 214.5 & 6.8 \\
Indonesia & 93.1 & 3.0 \\
Sudan & 85.0 & 2.7 \\
Congo, Dem. Rep. & 68.0 & 2.2 \\
Russian Federation & 65.2 & 2.1 \\
Australia & 54.2 & 1.7 \\
Argentina & 53.1 & 1.7 \\
Total & 1750 & 55.5 \\
\hline
\end{tabular}

Table 5. Number of Bhadla Solar Park plants required to replace coal power by country (Global Energy Monitor).

\begin{tabular}{cc}
\hline Country & Number of plants \\
\hline China & 475 \\
India & 100 \\
Japan & 28 \\
South Korea & 18 \\
Americas & \\
US states & 106 \\
Colombia & 1 \\
Europe & \\
Germany & 32 \\
Russia & 30 \\
Africa & \\
South Africa & 14 \\
\hline
\end{tabular}

Only if the governments of states were conducting their businesses with normativity, would they honour commitments in an ocean common pool regime like the Paris Agreement 2015. Yet, we live on Morgenthau's planet where states interact in international anarchy. Who can convince the above governments to dismantle coal power plants?

Morgenthau (1948) formulated the theory that states pursue egoism like individuals, always being prepared to defend their interests against any threat. The International system is a Hobbesian jungle with little normativity, which is why intergenerational coordination fails on environmental issues.

\section{Problematics of Environmental Coordination}

1) Information: people still ask the question that Wildavsky (1997) raised 
posthumously: is it really true? Global warming is a theory and the evidence can never become 100 percent. Uncertainty concerns: a) what temperatures can humans support, and b) how fast will temperatures go up? The amount of $\mathrm{CO}_{2}$ is steady on the Keeling scale due to COVID, but $\mathrm{CH}_{4}$ may rise now as the permafrost thaws-how dangerous? Deluteness and intermittency may lead government to distrust renewable power and look for e.g. thorium power.

2) Incentives: the basic logic of the PD model applies also when we have an oceanic game with some 200 players or governments. The Nash solution still holds: defection for any finite repetition of the game. This is the free rider strategy to externality-Stern says global warming is the largest ever. What complicates intergovernmental coordination is that poor countries want the OECD's to foot the costs for energy transition, obliquely promised in Paris 2015.

The more the EU diminishes pollution, the longer the BIG POLLUTERS simply roll their thumbs.

3) Strategy: delay. Since energy transformation is costly and uncertain, the best is marginal changes. Technology advances rapidly-why bet on an inferior technique? Tomorrow superior solutions arrive-just wait! How about gigantic carbon capture with fusion energy?

4) Needs: energy demand has risen enormously since 1960 and is predicted to double up to 2050. More and more states will turn to renewable, but they will not reduce fossils significantly. At the end of the day, Superpowers need energy for military might and poor states need energy for development. All the energy agencies predict rising energy demand with stable fossils. If all cars become EV, where is all the electricity to from? Maybe dams dry up?

5) Tactics: pretending. Given the popular anxiety for Armageddon as climate change and species' extinction, the big polluters take only limited initiatives or build Potemkin villages.

Thus, the EU promises carbon neutrality by 2050 . At the same time, it allows Germany and Eastern Europe to burn massive amounts of dirty coal beyond 2030. Sweden imports biotrash to burn for heat and electricity. Similarly, pellets are cut in the US to be burned in Western Europe. China closes some coal plants and rebuilds a few elsewhere, sometimes abroad. India aims to use coal power for electricity to 300 million poorest. And the US hopes that fracking will make them the number one oil exporter.

\section{Conclusion}

Foreign policy is driven by expectations. As long as the big polluters expect few changes in the short run, they pay lip service to the theory of global warming (Schneider, 1989; Stern, 2006). Government expectations are not always rational, even though continuously updated legally or illegally-Brazil for instance.

Examination of COVID policy in the US leads one to observe CHAOS. The same observations apply to global climate change policy. The most likely scenario is that the Big Polluters-also BIG POWERS-recognize too late Hawking's 
irreversibility, provoking chaos, migrations as well as confrontation in war. A world based on opinion juries would be better than realpolitik.

The roles of China and India appear in a crystal clear manner in the above Tables. Yet, arguments for their extreme pollution quantities are widely different.

On the one hand, Indian governments refer to dismal poverty of the giant country with its millions of homeless and illiterate claiming that only coal power can bring electricity to all-unless the rich countries assist financially as they promised in Paris 2015. Confronted by an explosive growth in population, India is running out of options. Nuclear energy is too costly, hydraulic power too uncertain with rivers drying up. Solar power would require much land space and foreign investment. Besides communication in India depends upon fossil fuels, charcoal is used in poor families.

On the other hand, China has huge pollution for a difference reason, namely to become a Superpower like the USA and the EU. Having reduced poverty very significantly, China now has set its goals much higher-to become a global leader. This will require enormous amounts of energy which is why China now promises carbon neutrality first by 2060 - too late compared to the EU and California for Instance. See Figure 1.

The plan is to retain fossil fuel but increase renewables and nuclear energy meaning that pollution will not decrease markedly. China promises several countries generously to help with nor their economies, but continues with coal power at home.

According to the Dean of the Lee Kuan Yew School at Singapore the West should accept China's rise to NUMBER ONE (Mahbubani, 2018). No-for several reasons, one of which is environmentalism.

Speaking of global warming responsibility, it makes no sense to speak of history and the early use of fossils by the West. Nor is it relevant to refer to pollution per capita i.e. the GULF. Total GHC emissions must down NOW.

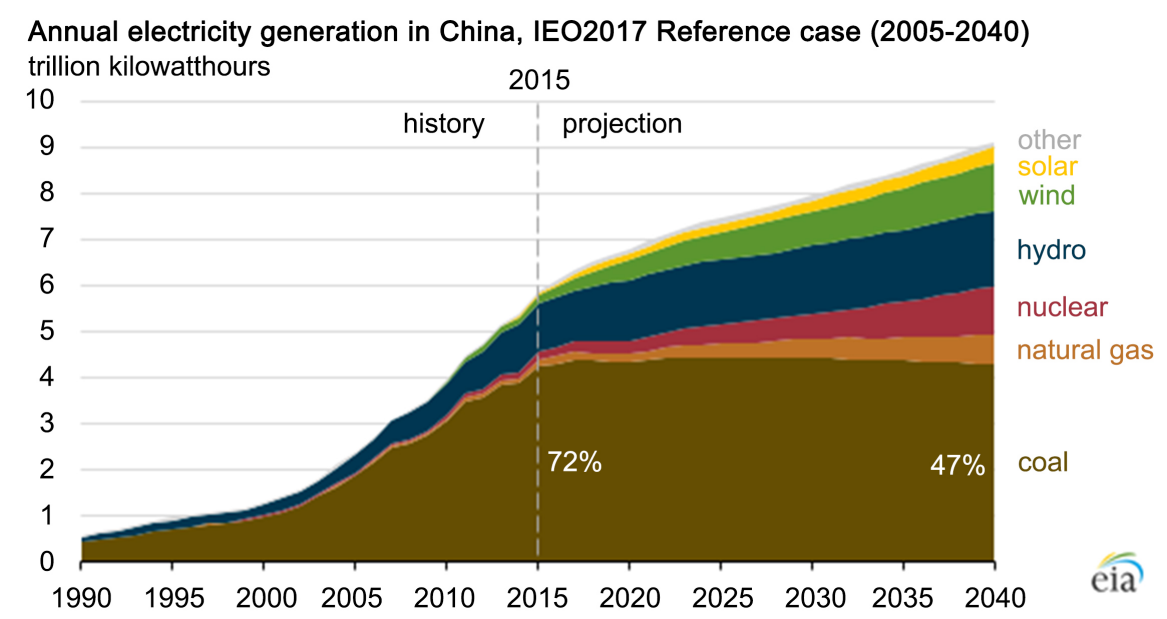

Figure 1. Projected China electricity generation by source (EIA). Source: U.S. Energy Information Administration (EIA, 2017). International Energy Outlook 2017. 


\section{Conflicts of Interest}

The author declares no conflicts of interest regarding the publication of this paper.

\section{References}

Bull, H. (1977). The Anarchical Society. New York: Columbia U.P. https://doi.org/10.1007/978-1-349-24028-9

Burton, D. A. (n.d.). $\mathrm{CO}_{2}$ and $\mathrm{CH}_{4}$ Since 1800. http://sealevel.info/co2_and_ch4.html

Hobbes, T. (1651). Leviathan. Oxford: Oxford University Publishers. https://doi.org/10.1093/oseo/instance.00025178

Kelsen, H. (1952). Principles of International Law. New York: Rinehart.

Mahbubani, K. (2018) Has the West Lost It? London: Penguin.

Morgenthau, H. (1948). Politics among Nations. New York: Mcgraw-Hill.

Schneider, S. H. (1989). The Greenhouse Effect: Science and Policy. Science, 243, 771-781. https://doi.org/10.1126/science.243.4892.771

Stern, N. (2006). Stern Review on the Economics of Climate Change (Pre-Publication Edition). Executive Summary. London: HM Treasury.

Teitel, R. (2011). Humanity's Law. Oxford: Oxford University Press. https://doi.org/10.1093/acprof:oso/9780195370911.001.0001

Waltz, K. (2008). Realism and International Politics. London: Routledge.

Wildavsky, A. (1997). Is It Really True? Cambridge: Harvard U.P. 